\title{
Faktor-Faktor yang Berhubungan dengan Kualitas Hidup Pasien Hemodialisis
}

\author{
Siti Fadlilah \\ Program Pendidikan Profesi Ners, Universitas Respati Yogyakarta, Indonesia \\ Email: sitifadlilah@ respati.ac.id
}

\begin{abstract}
Factors that are related to Quality of Life for Hemodialysis Patients. The incidence of kidney failure worldwide continues to increase. Kidney failure patients are dependent on hemodialysis therapy. The implementation of hemodialysis therapy 2-3 times a week for 3-4 hours will cause boredom and boredom. This will affect the quality of life of patients with chronic kidney failure. This study to determine the relationship of age, sex, education, duration of hemodialysis, source of support, and family support to the quality of life of hemodialysis patients in Panembahan Senopati General Hospital Bantul Yogyakarta. This research used descriptive correlational with cross sectional approach. The samples were patients undergoing hemodialysis therapy at Panembahan Senopati Regional General Hospital Bantul taken by accidental sampling amounting to 71 respondents. Data collecting used a questionnaire. Bivariate analysis used the Spearman Rank statistical test. Most of the respondents were age range 46-60 years as many as 48 people $(67.6 \%)$, male sex as many as 40 people $(56.3 \%$, high school education as many as 33 people $(46,5 \%)$, duration of 1-3 years hemodialysis range as many as 46 people $(64.8 \%)$, and sources of support from husband/wife as many as 40 people $(56.3 \%)$. Most respondents were getting enough family support as many as 31 people $(43.7 \%)$ and adequate quality of life of 35 people (49.3\%). Bivariate analysis of age, sex, education, duration of hemodialysis, and family support with quality of life obtained p-value 0.027 ; $0.758 ; 0.004 ; 0.0930 .015$; and 0.000 . There was a significant relationship between age, education, hemodialysis duration, and family support for the quality of life of hemodialysis patients in Panembahan Senopati Regional General Hospital, Bantul. While gender and source of support had no relation to the quality of life of hemodialysis patients in Panembahan Senopati Regional General Hospital Bantul.
\end{abstract}

Keywords: Family support, Hemodialysis, Hemodialysis duration, Quality of life

\begin{abstract}
Abstrak: Faktor-Faktor yang Berhubungan dengan Kualitas Hidup Pasien Hemodialisis Angka kejadian gagal ginjal di seluruh dunia terus meningkat. Pasien gagal ginjal ketergantungan dengan terapi hemodialisis, pelaksanaan terapi hemodialisis 2-3 kali seminggu selama 3-4 jam akan menimbulkan rasa bosan dan jenuh. Hal ini akan memengaruhi kualitas hidup pasien gagal ginjal kronis. Tujuan penelitian ntuk mengetahui hubungan umur, jenis kelamin, pendidikan, lama hemodialisis, sumber dukungan, dan dukungan keluarga dengan kualitas hidup pasien hemodialisis di RSUD Panembahan Senopati Bantul. Metode penelitian ini adalah deskriptif korelasional dengan pendekatan cross sectional dan menggunakan accidental sampling. Sampel pada penelitian ini adalah pasien yang menjalani terapi hemodialisis di Rumah Sakit Umum Daerah Panembahan Senopati Bantul yang berjumlah 71 responden. Pengambilan data menggunakan kuesioner. Analisis bivariat menggunakan uji statistik Spearman Rank. Sebagian besar responden adalah rentang usia 46-60 tahun sebanyak 48 orang $(67,6 \%)$, jenis kelamin laki-laki sebanyak 40 orang (56,3\%, pendidikan SMA sebanyak 33 orang (46,5\%), lama hemodialisis rentang 1-3 tahun sebanyak 46 orang $(64,8 \%)$, dan sumber dukungan dari suami/istri sebanyak 40 orang $(56,3 \%)$. Paling banyak responden adalah mendapat dukungan keluarga cukup sebanyak 31 orang $(43,7 \%)$ dan kualitas hidup kategori cukup yaitu sebanyak 35 orang (49,3\%). Analisis bivariat umur, jenis kelamin, pendidikan, lama hemodialisis, dan dukungan keluarga dengan kualitas hidup didapatkan $p$-value 0,$027 ; 0,758 ; 0,004 ; 0,093 ; 0,015$; dan 0,000 . Ada hubungan yang bermakna antara umur, pendidikan, lama hemodialisis, dan dukungan keluarga dengan kualitas hidup pasien hemodialisis di Rumah Sakit Umum Daerah Panembahan Senopati Bantul. Sedangkan jenis kelamin dan sumber dukungan tidak mempunyai hubungan dengan kualitas hidup pasien hemodialisis di Rumah Sakit Umum Daerah Panembahan Senopati Bantul.
\end{abstract}

Kata kunci: Dukungan Keluarga, Hemodialisis, Lama Hemodialisis, Kualitas hidup 


\section{PENDAHULUAN}

Gagal ginjal merupakan penyebab kematian pasien rawat inap di rumah sakit dengan presentase sekitar 3,16\% (Corwin, 2001). Gagal ginjal kronis adalah kerusakan ginjal yang terjadi selama atau lebih tiga bulan dengan laju filtrasi glomerulus kurang dari $60 \mathrm{ml} / \mathrm{men} .11,73 \mathrm{~m}^{2}$ (Pernefri, 2003). Gagal ginjal kronik merupakan masalah medik, sosial dan ekonomi yang sangat besar bagi pasien dan keluarganya, khususnya di negara-negara yang sedang berkembang yang memiliki sumber terbatas untuk membiayai pasien gagal ginjal terminal (Pahlevi, 2013).

Berdasarkan laporan Perhimpunan Nefrologi Indonesia (Pernefri) (2011), diketahui bahwa total insiden GGK pasien baru dan aktif di tahun 2011 adalah 22.304. Prevalensi usia menunjukkan terbanyak pada kelompok usia 4554 tahun $27 \%$. Sebagian besar pasien penyakit ginjal datang mencari pertolongan dalam keadaan terlambat dan pada stadium tidak dapat pulih. Hal ini disebabkan karena penyakit ginjal pada stadium awal umumnya tidak bergejala. Perawatan ginjal fase pre-dialitik jarang dilakukan.

Hemodialisis adalah suatu teknologi tinggi sebagai terapi pengganti fungsi ginjal untuk mengeluarkan sisa-sisa metabolisme atau racun tertentu dari peredaran darah manusia. Hemodialisis digunakan bagi pasien dengan tahap akhir gagal ginjal atau pasien dengan penyakit akut yang membutuhkan dialisis dalam waktu singkat (Haryono, 2013).

Di Indonesia, hemodialisis dilakukan 2-3 kali seminggu dengan setiap hemodialisis dilakukan selama 4-5 jam. Komplikasi akut hemodialisis adalah komplikasi yang terjadi selama hemodialisis berlangsung. Komplikasi yang sering terjadi diantaranya hipotensi, kram otot, mual dan muntah, sakit kepala, sakit dada, sakit punggun, gatal, demam, dan menggigil (Penefri, 2003).

Pasien yang menjalani hemodialisis jangka panjang harus dihadapkan dengan berbagai masalah seperti masalah finansial, kesulitan dalam mempertahankan pekerjaan, dorongan seksual berkurang, depresi dan ketakutan terhadap kematian. Hal ini akan memengaruhi kualitas hidup pasien gagal ginjal kronis (Smeltzer \& Bare, 2002). Kualitas hidup merupakan keadaan yang membuat seseorang mendapatkan kepuasan atau kenikmatan dalam kehidupan sehari-hari. Kualitas hidup tersebut menyangkut kesehatan fisik dan kesehatan mental (Saragih, 2010).
Kualitas hidup pada pasien GGK dengan hemodialisis yang diperoleh cukup baik dan panjang umur tertinggi sampai sekarang 14 tahun (Rahardjo dkk., 2006). Sasmito (2015), mengatakan bahwa pasien hemodialisis dengan kualitas hidup yang rendah akan meningkat mortalitasnya dibandingkan dengan populasi normal. Penilaian tentang kualitas hidup merupakan indikator penting untuk menilai keefektifan tindakan hemodialisis yang diberikan, sehingga kualitas hidup juga menjadi tujuan penting dalam pengobatan penyakit gagal ginjal kronik tahap akhir.

\section{METODE}

Jenis penelitian ini adalah penelitian kuantitatif dengan rancangan penelitian deskriptif korelasional dan desain penelitian adalah cross sectional. Pengambilan data pada 28 April sampai dengan 28 Mei 2017. Populasi dalam penelitian ini adalah pasien hemodialisis yang ada di Rumah Sakit Umum Daerah Panembahan Senopati Bantul Yogyakarta berjumlah 241 pasien. Sampel pada penelitian ini adalah pasien yang menjalani terapi hemodialisis di Rumah Sakit Umum Daerah Panembahan Senopati Bantul berjumlah 71 responden yang sesuai kriteria.

Adapun kriteria Inklusi yang ditetapkan oleh peneliti yaitu: pasien yang berusia 21-60 tahun, pendidikan terakhir keluarga minimal SD, responden yang tinggal satu rumah dengan keluarga, pasien yang menderita penyakit gagal ginjal, pasien yang menjalani terapi hemodialisis rutin. Sedangkan kriteria eksklusi adalah pasien yang mengalami gangguan penglihatan dan pendengaran dan pasien yang mengalami komplikasi intra dialisat.

Teknik pengambilan sampel pada penelitian ini menggunakan accidental sampling. Variabel independen pada penelitian ini yaitu umur, jenis kelamin, pendidikan, lama hemodialisis, sumber dukungan, dan dukungan keluarga. Variabel dependen pada penelitian ini yaitu kualitas hidup pasien hemodialisis.

Pengambilan data menggunakan kuesioner identitas responden (umur, jenis kelamin, pendidikan, lama $\mathrm{HD}$, dan sumber dukungan keluarga) dukungan keluarga dengan empat aspek (informasi, penghargaan, emosi, dan instrumental, kualitas hidup modifikasi dari The World Health Organization Quality of Life (WHOQOL-BREF). Analisis bivariat menggunakan uji statistik Spearman Rank. 
Penelitian ini telah memenuhi persyaratan etik penelitian sehigga mendapatkan keterangan kelaikan etik (ecthical clearance) dari Komisi Etik Penelitian Universitas Respati Yogyakarta No. 431.4/FIKES/PL/IV/2017.

\section{HASIL}

Tabel 1. Karakteristik Responden

\begin{tabular}{lrr}
\hline Karakteristik responden & Jumlah & \%) \\
\hline Umur (tahun) & & \\
$21-35$ tahun & 6 & 8,4 \\
36-45 tahun & 17 & 24,0 \\
46-60 tahun & 48 & 67,6 \\
\hline Jenis kelamin & & \\
Laki-laki & 40 & 56,3 \\
Perempuan & 31 & 43,7 \\
\hline Pendidikan & & \\
SD & 10 & 14,1 \\
SMP & 28 & 39,4 \\
SMA & 33 & 46,5 \\
\hline Lama Hemodialisis & & \\
<6 bulan & 14 & 19,7 \\
6-11 bulan & 9 & 12,7 \\
1-3 tahun & 46 & 64,8 \\
$>3$ tahun & 2 & 2,8 \\
\hline Sumber Dukungan Keluarga & & \\
Suami/Istri & 40 & 56,3 \\
Orang Tua & 7 & 9,9 \\
Anak & 24 & 33,8 \\
\hline Dukungan Keluarga & & \\
Baik & 28 & 39,4 \\
Cukup & 31 & 43,7 \\
Kurang & 12 & 16,9 \\
\hline Kualitas Hidup & & \\
Baik & 27 & 38,0 \\
Cukup & 35 & 49,3 \\
Kurang & 9 & 12,7 \\
\hline
\end{tabular}

Pada tabel 1 diketahui bahwa pasien yang menjalani terapi hemodialisis yang ada di Rumah Sakit Umum Daerah Panembahan Senopati Bantul sebagian besar berusia 46-60 tahun sebanyak 48 responden $(67,6 \%)$. Jenis kelamin sebagian besar adalah laki-laki sebanyak 40 responden $(56,3 \%)$. Paling banyak pasien telah melakukan hemodialisis 1-3 tahun sebanyak 46 responden $(64,8 \%)$. Tingkat pendidikan pasien terbanyak adalah tamat SMA sebanyak 33 responden $(46,5 \%)$. Sumber dukungan keluarga sebagian besar adalah berasal dari Suami/istri sebanyak 40 responden $(56,3 \%)$.

Berdasarkan tabel 1 diketahui juga mayoritas dukungan keluarga pasien hemodialisis paling banyak kategori cukup yaitu sebanyak 31 orang $(43,7 \%)$ dan responden memiliki kualitas hidup yang cukup yaitu sebanyak 35 orang $(49,3 \%)$

Pada tabel 2 diketahui analisis hubungan umur, pendidikan, lama HD, dan dukungan sosial dengan kualitas hidup didapatkan $p$-value 0,027 ; 0,$004 ; 0,014 ;$ dan 0,000. Hal tersebut menunjukkan ada hubungan antara umur, pendidikan, lama $\mathrm{HD}$, dan dukungan sosial dengan kualitas hidup pasien hemodialisis di RSUD Panembahan Senopati Bantul.

Sedangkan analisis hubungan jenis kelamin dan sumber hubungan dengan kualitas hidup didapatkan $p$-value 0,758 dan 0,093 . Hasil menunjukkan tidak ada hubungan jenis kelamin dan sumber hubungan dengan kualitas hidup pasien hemodialisis di RSUD panembahan Senopati Bantul. 
Tabel 2. Faktor-Faktor yang Berhubungan dengan Kualitas Hidup Pasien Hemodialisis

\begin{tabular}{|c|c|c|c|c|c|c|c|c|c|}
\hline \multirow{3}{*}{$\begin{array}{c}\text { Variabel } \\
\text { Independen }\end{array}$} & \multicolumn{8}{|c|}{ Kualitas Hidup } & \multirow{3}{*}{ p-value } \\
\hline & \multicolumn{2}{|c|}{ Kurang } & \multicolumn{2}{|c|}{ Cukup } & \multicolumn{2}{|c|}{ Baik } & \multicolumn{2}{|c|}{ Total } & \\
\hline & f & $\%$ & f & $\%$ & f & $\%$ & $\mathbf{F}$ & $\%$ & \\
\hline \multicolumn{9}{|l|}{ Umur } & \multirow{5}{*}{0,027} \\
\hline $21-35$ & 0 & 0,0 & 1 & 1,4 & 8 & 11,3 & 9 & 12,7 & \\
\hline $36-45$ & 1 & 1,4 & 7 & 9,9 & 7 & 9,9 & 15 & 21,1 & \\
\hline $46-59$ & 8 & 11,3 & 27 & 38,0 & 12 & 16,9 & 47 & 66,2 & \\
\hline Total & 9 & 12,7 & 35 & 49,3 & 27 & 38,0 & 71 & 100,0 & \\
\hline \multicolumn{9}{|l|}{ Jenis Kelamin } & \multirow{4}{*}{0.758} \\
\hline Laki-laki & 3 & 4,2 & 21 & 29,6 & 16 & 22,5 & 40 & 56,3 & \\
\hline Perempuan & 6 & 8,5 & 14 & 19,7 & 11 & 15,5 & 31 & 43,7 & \\
\hline Total & 9 & 12,7 & 35 & 49,3 & 27 & 38,0 & 71 & 100,0 & \\
\hline \multicolumn{9}{|l|}{ Pendidikan } & \multirow{5}{*}{0,004} \\
\hline $\mathrm{SD} / \mathrm{MI}$ & 1 & 1,4 & 8 & 11,3 & 1 & 1,4 & 10 & 14,1 & \\
\hline $\mathrm{SMP} / \mathrm{MTs}$ & 5 & 7,0 & 15 & 21,1 & 8 & 11,3 & 28 & 39,4 & \\
\hline SMA/MA & 3 & 4,2 & 12 & 16,9 & 18 & 25,4 & 33 & 46,5 & \\
\hline Total & 9 & 12,7 & 35 & 49,3 & 27 & 38,0 & 71 & 100,0 & \\
\hline \multicolumn{9}{|c|}{ Sumber Dukungan } & \multirow{5}{*}{0,093} \\
\hline Suami/Istri & 5 & 7,0 & 15 & 21,1 & 20 & 28,2 & 40 & 56,3 & \\
\hline Orang Tua & 0 & 0,0 & 1 & 1,4 & 5 & 7,0 & 6 & 8,5 & \\
\hline Anak & 4 & 5,6 & 19 & 26,8 & 2 & 2,8 & 25 & 35,2 & \\
\hline Total & 9 & 12,7 & 35 & 49,3 & 27 & 38,0 & 71 & 100,0 & \\
\hline \multicolumn{9}{|l|}{ Lama HD } & \multirow{6}{*}{0,015} \\
\hline$<6$ bulan & 1 & 1,4 & 3 & 4,2 & 7 & 9,9 & 11 & 15,5 & \\
\hline $6-11$ bulan & 2 & 2,8 & 4 & 5,6 & 6 & 8,5 & 12 & 16,9 & \\
\hline $1-3$ tahun & 11 & 15,5 & 7 & 9,9 & 5 & 7,0 & 23 & 32,4 & \\
\hline$>3$ tahun & 13 & 18,3 & 9 & 12,7 & 3 & 4,2 & 25 & 35,2 & \\
\hline Total & 27 & 38,0 & 23 & 32,4 & 21 & 29,6 & 71 & 100,0 & \\
\hline \multicolumn{9}{|c|}{ Dukungan Keluarga } & \multirow{5}{*}{0,000} \\
\hline Kurang & 5 & 7,0 & 7 & 9,9 & 0 & 0,0 & 12 & 16,9 & \\
\hline Cukup & 4 & 5,6 & 25 & 35,2 & 2 & 2,8 & 31 & 43,7 & \\
\hline Baik & 0 & 0,0 & 3 & 4,2 & 25 & 35,2 & 28 & 39,4 & \\
\hline Total & 9 & 12,7 & 35 & 49,3 & 27 & 38,0 & 71 & 100,0 & \\
\hline
\end{tabular}

\section{PEMBAHASAN}

Berdasarkan tabel 1 menunjukkan dari 71 responden, didapatkan responden yang memiliki kualitas hidup kategori baik sebanyak 27 responden $(38,0 \%)$. Sedangkan kualitas hidup kategori cukup sebanyak 35 responden $(49,3 \%)$, dan kurang sebanyak 9 responden $(12,7 \%)$. Hasil tersebut menunjukkan mayoritas responden memiliki kualitas hidup pasien hemodialisis dalam kategori cukup baik

Kualitas hidup pasien CKD yang menjalani hemodialisa cukup menarik perhatian bagi profesional kesehatan, karena masalah kualitas hidup menjadi sangat penting dalam pemberian layanan keperawatan yang menyeluruh bagi pasien, dengan harapan pasien dapat menjalani hemodialisa dan mampu bertahan hidup walau dengan bantuan mesin dialisa (Utami, 2015).
Hasil tabel 2 menunjukkan uji korelasi Spearman diperoleh hubungan umur, pendidikan, lama HD, dan dukungan sosial dengan kualitas hidup didapatkan $p$-value 0,$027 ; 0,004 ; 0,014$; dan $0,000 \quad(p<0,05)$ yang berarti terdapat hubungan yang signifikan antara ada hubungan antara umur, pendidikan, lama HD, dan dukungan sosial dengan kualitas hidup pasien hemodialisis di RSUD panembahan Senopati Bantul.

Tabel 2 menunjukkan hasil tabulasi silang diketahui responden dengan umur 21-35 tahun tidak ada yang mempunyai kualitas hidup kurang, sedangkan pada responden umur 36-45 dan 46-59 tahun terdapat 1 dan 8 responden yang mempunyai kualitas hidup kurang. Hasil yang sama juga diperoleh dalam penelitian Septiwi (2010), semakin umur meningkat didapatkan adanya penurunan kualitas hidup. Hal ini sesuai dengan teori yang dikemukakan oleh Paraskevi (2011); Kizilcik et al (2012); Verapan et al 
(2012), (dalam Mailani 2015) usia pasien yang berusia lanjut lebih cendrung mempunyai kualitas hidup yang lebih buruk dan cendrung lebih depresi.

Pendidikan merupakan salah satu faktor yang mempengaruhi kualitas hidup responden. Berdasarkan tabel 2 diketahui bahwa jenjang SMA/SMK sebanyak 33 orang $(46,5 \%)$ dan paling banyak mempunyai kualitas hidup kategori baik yaitu sebanyak 18 orang $(25,4 \%)$ dan kategori cukup sebanyak 12 orang $(16,9 \%)$. Pada jenjang SD/MI sebanyak 10 orang $(14,1 \%)$, terdapat 8 orang $(11,3 \%)$ mempunyai kualitas hidup kategori cukup dan 1 orang $(1,4 \%)$ mempunyai kualitas hidup kategori kurang. Pada jenjang SMP/MTs sebanyak 28 orang $(39,4 \%)$ dan paling banyak mempunyai kualitas hidup kategori cukup sebanyak 15 orang $(21,1 \%)$.

Data tersebut menunjukkan kualitas hidup pasien menjalani hemodialisis dipengaruhi oleh faktor pendidikan dimana semakin tinggi tingkat pendidikan semakin baik kualitas hidup pasien yang menjalani hemodialisis. Hal tersebut sesuai dengan teori Ghozally (dalam Larasati 2012), kualitas hidup akan meningkat seiring dengan tingginya tingkat pendidikan yang didapatkan oleh individu, hasil penelitian menunjukkan tingginya signifikasi perbandingan dari pasien yang berpendidikan tinggi meningkat dalam keterbatasan fungsional yang berkaitan dengan masalah emosional dari waktu ke waktu dibandingkan dengan pasien yang berpendidikan rendah serta menemukan kualitas hidup yang lebih baik bagi pasien berpendididkan tinggi dalam domain fisik dan fungsional, khususnya dalam fungsi fisik, energi/kelelahan, sosial fungsi, dan keterbatasan dalam peran berfungsi terkait dengan masalah emosional.

Hasil penelitian yang mendukung yaitu penelitian Wahl, dkk dalam Nofitri (2009), menemukan bahwa kualitas hidup akan meningkat seiring dengan lebih tingginya tingkat pendidikan yang didapatkan oleh individu.

Tabel 2 nmenunjukkan adanya hubungan signifikan antara lama hemodialisis dengan kualitas hidup pada pasien gagal ginjal kronik (GGK) di RSUD Panembahan Senopati bantul dengan $p$-value 0,015. Hasil menunjukkan semakin lama hemodialisis yang dilakukan oleh pasien gagal ginjal kronik, kualitas hidup yang dialami semakin kurang sedangkan pasien yang baru menjalani terapi hemodialisis kualitas hidupnya baik. Dari observasi yang dilakukan banyak responden yang merasa pasrah dengan apa yang sudah menjadi takdirnya saat ini dan menerima semuanya tanpa ada rasa takut dalam menjalani hemodialisis.
Seperti yang telah diuraikan sebelumnya, tindakan hemodialisis sengat erat hubungannya dengan kualitas hidup pasien, dimana kualitas hidup meliputi 4 aspek yaitu aspek fisik, psikologi, sosial dan lingkungan. Dari penelitian yang telah dilakukan Landreneau et al (2010), menyimpulkan bahwa kualitas hidup pasien yang menjalani transplantasi ginjal lebih baik dibandingkan dengan pasien yang menjalani hemodialisis.

Dukungan keluarga erat kaitannya dalam menunjang kualitas hidup seseorang. Hal ini dikarenakan kualitas hidup merupakan suatu persepsi yang hadir dalam kemampuan, keterbatasan, gejala serta sifat psikososial hidup individu baik dalam konteks lingkungan budaya dan nilainya dalam menjalankan peran dan fungsinya sebagaimana mestinya. Hal tersebut ditunjukkan 12 orang $(16,9 \%)$ yang mendapatkan dukungan keluarga kurang, paling banyak mempunyai kualitas hidup kategori cukup yaitu sebanyak 7 orang $(9,9 \%)$. Diketahui 31 orang $(43,7 \%)$ yang mendapatkan dukungan keluarga cukup, paling banyak mempunyai kualitas hidup kategori cukup yaitu sebanyak 25 orang $(35,2 \%)$. Diketahui dari 28 orang $(39,4 \%)$ yang mendapatkan dukungan keluarga cukup, sebagian besar mempunyai kualitas hidup baik yaitu sebanyak 25 orang $(35,2 \%)$.

Hasil penelitian lain yang mendukung penelitian Sukriswati (2016), yang meneliti tentang hubungan dukungan keluarga dengan kualitas hidup pasien gagal ginjal kronik yang menjalani hemodialisa di RSUD Moewardi Surakarta didapatkan hasil $p$-value $=0,000$ $(p<0,005)$ yang artinya ada hubungan yang signifikan antara dukungan keluarga dengan kualitas hidup pasien gagal ginjal kronik yang menjalani hemodialisa.

Dukungan keluarga pada penelitian ini adalah persepsi pasien hemodialisis tentang sikap, tindakan, dan penerimaan keluarga terhadap dirinya selama menjalani hemodialisis. Bentuk dukungan keluarga sebagai berikut, dukungan emosional, dukungan penghargaan, dukungan informasional dan dukungan instrumental.

Faktor yang mempengaruhi dukungan keluarga antara lain, tahap perkembangan (usia), pendidikan atau tingkat pengetahuan, faktor emosi, spritual, praktik keluarga, faktor sosio ekonomi, dan latar belakang budaya. Pada penelitian ini faktor yang mempengaruhi dukungan keluarga salah satunya tahap perkembangan (usia). Semakin bertambah usia akan semakin berkembang pula daya tangkap dan pola pikirnya sehingga pengetahuan yang 
diperolehnya semakin membaik (Notoatmodjo, 2010)

Hasil penelitian ini mendukung penelitian Ningrum (2012), yang meneliti tentang hubungan dukungan keluarga dengan perilaku pada pasien hipertensi di wilayah kerja puskesmas minggir sleman yogyakarta, diperoleh nilai $p$ value $=0,000$. Dengan jumlah responden 58 orang sebagian besar reponden mendapat dukungan keluarga dalam kategori cukup yaitu sebanyak 36 orang $(62,1 \%)$.

Hasil menunjukkan tidak ada hubungan antara jenis kelamin dengan kualitas hidup pasien hemodialisis dengan $p$-value 0,758 . Tetapi pada tabel 2 dapat dilihat jumlah responden laki-laki dan perempuan yang mempunyai kualitas hidup kurang sebanyak 3 dan 6 , yang mempunyai kualitas hidup baik 16 dan 11. Hasil tersebut menunjukkan kualitas hidup pasien hemodialisis laki-laki lebih baik dibandingkan perempuan. Hasil penelitian ini mendukung teori Sofiana (2010), dimana pasien perempuan cendrung mempunyai kualitas hidup yang lebih rendah

\section{DAFTAR PUSTAKA}

Corwin. (2001). Buku Saku Patofisiologi. Jakarta: EGC.

Haryono, R. (2013). Keperawatan Medikal Bedah (Sistem Perkemihan). Yogyakarta: Rapha Publisher.

Landreneau, K., Lee, K., \& Landreneau, M.D. (2010). Quality of life in Patient Undegoing hemodialysis and Renal Transplantation-A meta-analytic Review. Nephorology Nursing Journal, 37 (1), 37 45.

Larasati, T.A (2012). Kualitas hidup pasien Diabetes militus Tipe 2 di RS Abdul Moeloek Propinsi Lampung. Jurnal Kedokteran dan Kesehatan Universitas Lampung, Vol2., No, 17-20.

Mailani, F. (2016). Kualitas Hidup Pasien penyakit Gagal Ginjal Kronnis yang Menjalani Hemodialisis: Systematic Review. Jurnal Ners, 11(1).

Ningrum, S.R. (2012). Hubungan Dukungan Keluarga Dengan Perilaku Makan Pada Pasien Hipertensi Di Wilayah Kerja Puskesmas Minggir Sleman Yogyakarta. (Skripsi. Stikes 'Aisyiyah Yogyakarta).

Nofitri. (2009). Kualitas Hidup Penduduk Dewasa di Jakarta. (Skripsi. Universitas Indonesia). Depok. Diunduh pada 11 September 2017. http://www.lontar.ui.ac.id dibandingkan dengan pasien berjenis kelamin laki-laki.

\section{SIMPULAN}

Hasil penelitian menunjukkan bahwa ada hubungan yang signifikan antara umur, pendidikan, lama HD, dan dukungan keluarga dengan kualitas hidup pasien. Sedangkan jenis kelamin dan sumber dukungan tidak menunjukkan adanya hubungan signifikan dengan kualitas hidup. Berdasarkan hasil penelitian diharapkan perawat ruang hemodialisis diharapkan dapat meningkatkan asuhannya agar kualitas pasien HD tetap baik. Pasien HD adalah pasien berulang sehingga interaksi dengan perawat akan selalu ada. Perawat dapat meningkatkan kualitas pasien dengan meningkatkan pengetahuan, mengoptimalkan dukungan keluarga, dan menjaga kualitas asuhan keperawatan.

Notoatmodjo, S. (2010). Metodologi Penelitian Kesehatan. Jakarta: RinekaCipta.

Pahlevi, A., \& Bachtiar, M. (2013). Gagal ginjal kronik et causa glomerulonefritis kronis yang disertai gastroenteritis. Jurnal Medula, 1(05), 14-20.

Perhimpunan Nefrologi Indonesia (Pernefri). (2003). Konsesus dialisis. Ed/1. Jakarta: Fakultas Kedokteran Universitas Indonesia.

Perhimpunan Nefrologi Indonesia (Pernefri). (2011). Konsesus dialisis. Ed/1. Jakarta: Fakultas Kedokteran Universitas Indonesia.

Rahardjo, P., Susalit, E. \& Suhardjono. (2006). Hemodialisis, In: Sudoyo AW, Setiyohadi B, Alwi I, Simadibrata KM, Setiati S, eds. Buku Ajar Ilmu Penyakit Dalam 4th ed. Pusat Penerbitan Departemen Ilmu Penyakit Dalam Fakultas Kedokteran Universitas Indonesia.

Saragih, D.A. (2010). Hubungan Dukungan Keluarga dengan Kualitas Hidup Pasien Gagal Ginjal Kronis yang Menjalani Terapi Hemodialisa di RSUP Haji Adam Malik Medan. (Skripsi, Fakultas Keperawatan, Universitas Sumatera Utara). Medan.

Sasmito, P., \& Wantonoro, W. (2015). Hubungan Pemenuhan Kebutuhan Seksual dengan 
Kualitas Hidup Pasien Gagal Ginjal Kronis di RS PKU Muhammadiyah Unit II Yogyakarta (Doctoral dissertation, STIKES'Aisyiyah Yogyakarta).

Septiwi, C. (2010). Hubungan Antara Adekuasi Hemodialisis dengan Kualitas Hidup Pasien Hemodialisis Di Unit Hemodialisis Rs. Prof. Dr. Magono Soekarjo Purwokerto. (Tesis. Universitas Indonesia). Depok.

Smeltzer, S, \& Bare. (2002). Buku Ajar Keperawatan Medikal Bedah. Jakarta: EGC.

Sofiana. (2010). Analisis faktor-faktor yang Berhubungan dengan Kualitas Hidup Pasien Penyakit Ginjal Kronik yang menjalani Hemodialisis di Rumah Sakit
Islma Fatimah Cilacap dan Rumah Sakit Umum Daerah Banyumas. (Tesis. Universitas Indonesia). Depok.

Sukriswati, I. (2016). Hubungan Dukungan Keluarga Dengan Kualitas Hidup Pasien Gagal Ginjal Kronik Yang Menjalani Hemodialisa Di Rsud Moewardi Surakarta. (Skripsi, Universitas Muhammadiyah Surakarta).

Utami, G. T. (2015). Hubungan Dukungan Keluarga Dengan Kualitas Hidup Pasien Gagal Ginjal Kronik Yang Menjalani Terapi Hemodialisis Di Rsud Arifin Achmad Pekanbaru. Jurnal Online Mahasiswa Program Studi Ilmu Keperawatan Universitas Riau, 2(1), 670681. 